\title{
REPRODUCING IDENTITY THROUGH REMEMBERING: CULTURAL TEXTS ON THE LATE SOVIET PERIOD
}

\author{
Kirsti Jõesalu, Raili Nugin
}

\begin{abstract}
This article explores some of the ways in which memories of the Soviet past shape the identities and creative work of six Estonian intellectuals born in the 1970s. Based on analysis of the four cultural texts they have produced (an exhibition, a feature film, a novel and a documentary) and biographical interviews with them, it is argued that the authors' birth frame has had an impact on how they interpret the late Soviet period. They share discursive practices about this period: mutual interpretative principles, which validate their common experience in discourses. Their experience of living in the Soviet system is limited to their childhood years only.

Sharing a kind of reflexive nostalgia about the era, they depict the late Soviet period somewhat ironically, with a touch of cynicism (in their cultural texts as well as in the interviews). Even though they do not oppose the official public discourse of the rupture of Soviet Estonia, they tend to accentuate and value everyday experience, thus contributing to 'normalisation' discourse of the Soviet period in Estonian memory landscapes. Childhood experiences of the late Soviet period constitute an integral part of these intellectuals' identities. By reproducing their identity in their cultural texts, they have a potential to deepen the memory templates already existing in public memory discourse, and also to contribute to the addition of new discourses and influencing the identity of others in society.
\end{abstract}

Keywords: late Soviet period, cultural texts, biographical interviews, nostalgia, communicative memory, post-Soviet memory culture

This article aims to discuss in what ways memories of the Soviet past can shape the identities of intellectuals and their cultural texts. Our special interest is dedicated to six intellectuals born in Estonia in the 1970s and their cultural texts that deal with the Soviet past in one way or the other. We argue that the fact that people were born in a certain time frame (the 1970s) has influenced the way the Soviet past is understood and represented. People born during the same period can share similar discursive practices (Corsten 1999). Relying on biographical interviews of the authors of four different cultural texts, we offer one possible interpretation of Soviet memories. We aim to point out the templates and constructions that this generation uses in describing their childhood 
and to show to what extent Soviet experience has a role in their identities. In our study we depart from social and cultural memory studies.

The focus of our article is to shed light on the interpretation of the late Soviet period, the 1960s-80s (defined by Yurchak as 'late socialism' in 2005: 31). ${ }^{1}$ The analysed cultural texts have the potential to shape the cultural memory of this era in society in general (Erll 2008: $390 \mathrm{ff}$.). We will ask how these intellectuals reproduce in their cultural texts the facets of their identity that were shaped by their childhood in the Soviet Union. How do they use their experience of the Soviet past as a cultural resource (Nugin 2011)? Which are the dominant discursive practices among them (Corsten 1999: 260)? How do they express their memories and how do they relate to other forms of memory in society?

\section{DISCONTINUITY AND NOSTALGIA - THE FEATURES OF ESTONIAN MEMORY CULTURE}

Remembering is a process that is individual as well as collective, being influenced by personal experience and public discourses about the past through different media. In this article, cultural memory is understood in a broader sense as an umbrella term for different phenomena. In German cultural memory theory, distinction between cultural and communication memories is common. The leading authors of the theory, Jan and Aleida Assmann, suggest that cultural memory consists of texts of 'high' culture that have lasted through time and create a framework for communication across the abyss of time (Assmann J. 1995; Assmann A. 1999, 2006). Communicative memory, on the other hand, is, according to the Assmanns, based on the memory that is passed on in everyday communication and stories that are told in informal environments. This memory type dates no more than three generations back, and it is not older than one hundred years: as long as living generations can remember the past (see more on distinction between communicative and cultural memory in $\mathrm{J}$. Assmann 1995; 2008: 110-113).

Our article deals with cultural texts on late socialism, which, according to the Assmanns' approach could be analysed only as a part of communicative memory as the time lag is too recent (less than one hundred years). Among others, Astrid Erll (2005: 112 ff.) has problematised chronological distinction between cultural and communicative memory (see also Welzer 2002, 2008). Additionally to the problem of time horizon, the question of 'high' and everyday culture arises here, especially when dealing with events from recent history that are already covered by cultural texts, but also communicated by those still alive with personal memories of these times. Erll has suggested that in 
this case the same historical context is treated as an object of both cultural and communicative memory, yet two different modes of remembering are used (Erll 2005: 115).

When dealing with contemporary texts, distinguishing the border between cultural and communicative memory can become complicated. Hence, in the following analysis we use the term cultural memory (while speaking about specific texts), which also includes communicative memory. We will point out that late socialism could be analysed in the framework of cultural as well as communicative memory.

In our definition, texts are not just written texts; we expand the definition and analyse also films, exhibitions and other forms of cultural production.

The questions of memory have often been related to the notion of generational consciousness (Misztal 2003; Corsten 1999; Mannheim 1993 [1952]). Being born in a certain period limits people to "a specific range of potential experience, predisposing them to a certain characteristic mode of thought and experience, and a characteristic type of historically relevant action" (Mannheim 1993 [1952]: 36). In other words, experiencing similar social conditions, events and environment in their socialising years influences the way that those born in a certain period organise their past and future. Thus, as pointed out by Michael Corsten (1999: 258-260), people in the same generation tend to create what he calls "discursive practices" - a semantic order by which time is organised. Those "discursive practices" are certain interpretative principles, which validate mutual experience in discourses (Corsten 1999: 261; Misztal 2003: 62; Weisbrod 2007: 22). Memory can also guide certain practices and enable people to understand the world by serving as a "meaning-making apparatus" (Schwartz 2000: 17, cited in Misztal 2003: 13). Different generations may consider different aspects of events in history important to be remembered and discursive practices shaped by one's age may also influence the way in which these events are remembered (Misztal 2003: 12-13, 83-91).

In the following, we will point out two interconnected categories in Estonian memory discourse: (a) discontinuity and (b) nostalgia. In our analysis section, we will demonstrate how our informants are influenced by both of these discourses. We will attempt to look into how the experienced memory expressed in biographical interviews and cultural texts are interlinked. 


\subsection{On discontinuity}

In Estonian post-Soviet memory studies, life writing and 'grand narratives' of 'Great History' have occupied a prominent position (topics like the World War II and Stalinist repressions, see, e.g., Aarelaid 2006; Anepaio 2003; Kõresaar 2005; Hinrikus 2005; Kõresaar \& Kuutma \& Lauk 2009, Kõresaar 2011). In the current article we will look beyond the questions of Great History, bringing in remembering of the everyday and using other sources in addition to life writing.

On the memory policy level (history books, official statements and politicians' speeches), the Soviet era in post-Soviet Estonia is interpreted in the framework of the discourse of rupture (Kõresaar 2005; Jõesalu \& Kõresaar forthcoming; Jõesalu 2012). Ene Kõresaar has used the notion 'prolonged rupture', in which the meaning of the Stalinist era is attributed to the entire Soviet period in Estonia (from 1940 to the end of the 1980s) (Kõresaar 2005: 151). Until the beginning of the 21 st century, the late Soviet era $(1960$ s-80s) was included in the discourse of 'rupture' in Estonian society. This discourse itself had developed at the end of the 1980s and the beginning of the 1990s in the anti-Soviet spirit of 'taking back Estonia's history' and was used by politicians to legitimate their everyday politics (restoring the previous republic) (Kõresaar 2005). In this case, rupture is seen as an interruption and deterioration of an idealised independence era (Jõesalu \& Kõresaar forthcoming).

This perception of rupture was mostly based on the experience of people born in the 1920s. From the beginning of the 21st century those born during the Soviet period, especially in the $1940 \mathrm{~s}-50 \mathrm{~s}$, started to contribute to the process of remembering. From that time on, interest in verbalising the experience of 'late socialism' increased remarkably (see Jõesalu \& Kõresaar forthcoming). People born during and after World War II tended to treat the Soviet period in the frame of 'normalisation' discourse, by bringing up in their memoires the experiences of their everyday lives and leaving public ideology aside. Normalisation discource itself is very heterogeneous, and is one of the discourses that is represented by those born during late socialism, who perceive their Soviet childhood as an exotic experience, comparing it with the experience of postSoviet generations (e.g. in Grünberg 2008).

Different discourses on the Soviet period - especially the discourse of rupture and discourse of normality - coexist in Estonian post-Soviet memory culture (Jõesalu \& Kõresaar forthcoming). Those discourses describe the Soviet experience on different levels and through different temporal horizons (Giesen 2004)2. In the current paper, we are concentrating on the experience of individuals born during late socialism, in the 1970 s, who have added their meaning to memory discourse since the beginning of the new century. Unlike earlier generations, 
who communicated their memories mainly through biographical texts, those born in the 1970s tend to use other memory mediums. In the analysis section we try to examine what their position is in terms of the previously described different discourses.

\subsection{On Nostalgia}

Nostalgia is a category that is closely related to the discourse of rupture. Taking into consideration the treatment of the Soviet era in the framework of rupture, nostalgia towards this era is often politicised and considered a threat to democracy (see, e.g., Masso 2010; Laar 2008). When using the concept of nostalgia in our analysis, we rely mainly on the works of anthropologist Daphne Berdhal (2010). In Berdahl's interpretation, nostalgia is a heterogeneous phenomenon. ${ }^{3}$ Analysing the former GDR, she has pointed out that nostalgia (in its German specific form Ostalgie $)^{4}$ can be treated as a counter-memory to dominant discourses of the past, and also a way to give the present its meaning. Berdhal has also suggested that one form of this nostalgia can be characterised through "cynicism, irony and parody" (Berdhal 2010: 131).

In addition to Berdahl's concept we will also use the notion of reflexive nostalgia. Svetlana Boym (2002), when studying Soviet nostalgia, has differentiated between restorative and reflexive nostalgia. The former is defined as nostalgia that recalls memories of the patriotic past and shapes a future based on those memories. This type of nostalgia is used to ideologise and mystify the past on a national and/or social level (legitimising current projects through past examples). Reflexive nostalgia, on the other hand, is a more general longing for the past, which also contributes to the meaning-making of the present.

In contemporary Estonia, Soviet nostalgia is stigmatised on the memory policy level, as it is perceived as restorative nostalgia. However, in other spheres - especially in the sphere of entertainment - interpretations are much more ambivalent and not necessarily restorative. As we will show later, even though in their biographical interviews our informants associate nostalgia with something negative and not their own (assigning its traits to earlier generations and stigmatising its manifestation), nostalgia in its different forms is not missing from their cultural texts and interviews altogether. The nostalgia in their texts is more playful, and, as pointed out by Berdahl, sometimes cynical and ironic (see also Grünberg 2008; Jõesalu \& Kõresaar forthcoming). 


\section{METHODOLOGY AND MATERIAL}

People born in the 1970s make an interesting object of research since they spent their childhood in late Soviet society and their transition years to adulthood coincided with the turbulent times in society when social structures were rearranged. Their coming of age took place simultaneously with the building of the new society (from socialism to liberal capitalism). ${ }^{5}$

Our purpose was to see if those born in the 1970s share a certain understanding of the Soviet past and how this is reproduced in cultural texts. By choosing texts from different cultural fields we hoped to be able to make more generalisations, searching for similar mnemonic templates in different cultural forms. In addition, we chose to interview the authors of the texts to get a broader base for our argument. The interviews provided such rich and interesting material that instead of being complementary, it turned out to be crucial in our dataset.

By selecting cultural texts, our aim was to choose the media that have the possibility to become a powerful "media of cultural memory" (Erll 2008: 390). The chosen texts use the 'experimental mode' in narrating. According to Astrid Erll, experimental modes are constituted by literary forms that represent the past as a recent, lived-through experience (ibid.). Here, the intermediality of the texts became crucial. Texts narrating similar topics constitute inter-medial dynamics and those texts support each other. Cultural texts hereby are understood in a broader sense, including written texts as well as films, exhibitions and the like, as all these cultural texts with their generalised aesthetic formulations are always part of general cultural memory (Erll 2008; A. Assmann 2006: 207). As Astrid Erll has put it: "Remembered events are transmedial phenomena, that is, their representation is not tied to one specific medium." (Erll 2008: 392) This applies also to our case: late socialism is the main playground in every chosen cultural text. These texts reproduce this particular period of the Soviet era, providing a scheme of interpretations for the memory community, this way also influencing the shaping of individual autobiographic memories (Erll 2008).

The cultural texts analysed are the following: (a) a design exhibition called Things in My Life (2000-2001), curated by Kai Lobjakas (1975) and Karin Paulus (1975); (b) the feature film Touched by the Unknown (2005), scenario by Urmas Vadi (1977), directed by Jaak Kilmi (1973); (c) a documentary called Disco and Atomic War (2009), written and directed by Jaak Kilmi and Kiur Aarma (1974); and (d) the novel A While (2009) by Jan Kaus (1971). The interval between publishing the texts is almost ten years, and during this decade the meaning of 'mature socialism' underwent several changes. When analysing the texts, we have tried to consider this temporal aspect. 
The authors of the texts were born between 1971 and $1977^{6}$ and with one exception, they were all born in Tallinn, the Estonian capital (although Kai moved to a Tallinn satellite town shortly before primary school, her childhood experiences are still very much connected to the capital). Urmas was born and raised in Tartu (the second largest city in Estonia). We find these circumstances important in the Estonian context. Firstly, all the authors have an urban background, which can differ to a certain extent from a rural childhood during the Soviet period. ${ }^{7}$ Another significant factor for those living in Tallinn and its outskirts is Finnish television, which provided the possibility to see how the capitalist world 'actually lived' and how it contradicted Soviet propaganda's idea of what it was like.

The interviews were conducted in July and August 2010, mainly at public places (cafés) in Tallinn and Tartu (Urmas), one interview (Kai and Karin) took place at one of the researcher's homes. We grouped the interviewees according to the cultural texts they had produced, i.e., the curators of the exhibition (Kai and Karin) were interviewed together as were the authors of the documentary (Jaak and Kiur), whereas Jan and Urmas were interviewed separately. The interview started off with questions about the authors' biographies and eventually led to their creative works, with specific questions about interpreting the chosen texts. The interviews lasted for two hours.

The interviews were recorded and transcribed and then read several times and coded by the authors separately. During the next stage of the analysis, the codes were compared and discussed, complementing and unifying each other's codes. The codes were then used to form inductive categories that related to interpretation of the late Soviet era. Then the texts were reread to compare them with the created categories. In our paper, we use the interviewees' first names when referring to their biographics; when discussing the cultural texts, we use their surnames.

In the following, four cultural texts are analysed through schematic narrative templates ${ }^{8}$ (Wertsch 2002: 60-62) that seemed important to the authors in their biographies as well as in their creative work. 


\section{ANALYSIS: REMEMBERING THE SOVIET PERIOD AND REPRODUCING IT IN TEXTS}

\subsection{Things in Life and Things on Stage: Exhibition Things in My Life (2000-2001)}

When interpreting late socialism, one of the mutual topics that keeps re-emerging in the interviews and cultural texts is concentration on material environment. When reminiscing about their childhood and adolescence, material environment becomes meaningful for our informants in terms of space as well as artefacts. Life story researchers have shown that things have an explanatory function in life stories (see Kirchenblatt-Gimblett 1989; Kõresaar 1998; Mohrmann 1991). This claim finds support in all of our interviews, as our informants thematised material culture in interpreting their identity as youngsters as well as today. For instance, Karin and Kai in their biographical interview pointed out that the scarcity of goods during their childhood caused a desire for things:

Karin: But this is important, these things are so important - that you'll get yourself foreign clothes of some sort, get yourself a shirt or trousers. I remember that I got myself culottes, probably from some shop that accepted vouchers ${ }^{9}$, and then I went swimming and they were stolen from me. I rushed home ... This was a real tragedy; I remember it so well. You just valued those things. This materialism ...

Kai: Yes, it made you value things. There's nothing to do, some desires were kind of left unsatisfied and ...

In a similar vein, Kiur points out the absence of things as one of the main characteristics of the Soviet period and, similarly to Kai and Karin, mentions the desires which originate from his childhood:

The absence of things tends to be more significant than their presence and because of that ... People, who kind of haven't had things, once they get them later in life, start procuring them, then they overdo it. [---] And there [in the Soviet era], if one knew well enough Nadya or somebody else who was selling there (and locals did know), then you could get from under the counter - these were rationed goods, ok - little cheesecakes covered in chocolate and these cocoa crème fraiche cupcakes - this has resulted in a lifelong fixation on this stuff. I couldn't afford them back then and now I buy six pieces and eat them in a row. (Kiur) 
The first cultural text that this paper concentrates on is the Things in My Life exhibition, which opened first in Tartu and then in Tallinn. ${ }^{10}$ It is also chronologically the first cultural text among those analysed. The exhibition presented things designed during the Soviet period: the physical world that surrounded those born in the 1970s. The museumification of Soviet everyday life had not taken place before the new millennium (unlike in Germany, see Berdahl 2010: $54)^{11}$. Susan Gille has suggested that for the outburst of nostalgia a conviction is needed that the previous era is gone never to return. In the GDR, radical changes were made right away and therefore nostalgia emerged there earlier than in other former socialist republics (Gille 2010: 282). Nostalgia was present in Estonian society in the 1990s as well, but this was a restorative nostalgia towards the pre-World War II republic, in which the Soviet period was "cut off" (Kõresaar 2005).

The curators of the exhibition, Kai and Karin, imply that up to that time Estonian exhibiting culture had concentrated on unique design. Therefore, little attention had been paid to everyday design, let alone to Soviet everyday design. Hence, the authors raised two topics - first, artefacts of everyday life and second, everyday life as such during that era. Explaining the meaning behind the title of the exhibition, Kai points out that this is their own story, that the things presented at the exhibition are very meaningful for them:

For us it was also like a broadening of the picture, something that you had always seen in exhibitions ... that this unique art was valued, you had been in the middle of this. But that this everyday environment ... I think that we searched for a little bit ... this came ... I flicked through some journals and thought how to express myself [laughs]. And then it clicked. Well it seemed like a big bite, and then this title - Things in My Life - provided a means for backing off; you can start out from yourself, from two persons, you can start out together. (Kai)

In 2000, when the exhibition opened at the Estonian National Museum (ENM), the different experiences in the Soviet era - the repressions of the 1940s and 1950s and the subsequent 'peaceful' decades - were not differentiated in public discourse. The cultural texts as mentioned above, along with the rest of public memory culture generally reproduced the discourse of rupture. As the exhibition is a temporary phenomenon by nature, we concentrate in our analysis on the reception at that time, photographs of the exhibition (there was no catalogue) and workplans. ${ }^{12}$ The exhibition displayed things that had surrounded most of the visitors in their homes as well as in public spaces during the Soviet period. The curators pointed out that they wished to value things from the Soviet era: 
"[---] to show that in spite of ideology the design of the Soviet period is interesting and relevant to date" (Karin).

The curators themselves saw the exhibition as an impulse for other cultural texts dealing with everyday Soviet life, which were produced later on, at the beginning of the 21st century, especially in other museums. Within this framework, Karin expresses her pride and points out that they were the first to exhibit the lamp called Old Thomas ${ }^{13}$, which today is seen as a symbol of the commodification of nostalgia and marketed as a symbol of everyday Soviet life.

In the article that the curators published during the exhibition, there is an explicitly expressed wish to bring the Soviet period back to public memory culture, polemising with those who have left this particular material culture behind:

An arrogant and disgusting attitude towards things emanating from the socialist era of scarce possibilities as well as juxtaposition to supposed design 'classics' is at times downright unjust. The material outcomes of modernist ideology, suited so well to the socialist order, are at times of poor quality and shoddy material, but once they are separated from their context, their strong formal side has to be acknowledged. (Lobjakas \& Paulus 2000: 9)

In their biographical interview, Kai and Karin stressed that they wished to oppose the dominant treatment of the post-Soviet period in 20th century design and architectural history, the treatment that supported the discourse of rupture and in which pre-war Estonian things were especially valued. At the same time they admit that the cultural codes they had used in exhibiting artefacts were understandable mainly to people of their own age, since the codes were based on the mutual discursive practices (Corsten 1999) among those born in the late Soviet period.

For folks of our own age it seemed cool, but for people who were forced to consume these things, [for them it was different] one gets angry and another one says, well, that you don't know how to approach it as an object to be shown at an exhibition, that leaves you kind of baffled. (Kai)

For older generations, the museumification of everyday Soviet life caused amazement and, at times, even distaste. Thus, an acknowledged art historian Helena Kuma (b. 1921) published an open letter after visiting the exhibition. In the letter, she questioned the entire concept of the exhibition:

The fact that the exhibition does not include first-rate Soviet industrial art creates the impression that this was deliberate, and only random and 
in part dubious objects or direct copies of Finnish design are on display. (Kuma 2001) $)^{14}$

Even half a decade later, in 2006, visitors commented on another exhibition at the ENM about the food culture of the Soviet period, expressing their disapproval of the museumification of Soviet everyday experience (see, e.g., "grandmother from Pärnu County", guestbook of the ENM). Berdahl (2010: 59) has suggested that these kinds of archival practices that historicise the present can have quite an uncanny effect on the people who actually live in a similar environment. Our informants, however, had distanced themselves from the Soviet-period material environment - they had created their own new homes in non-Soviet surroundings. This distancing also creates preconditions for nostalgia. Zsuzsa Gille has stressed that a time-lag is needed for the emergence of nostalgia, and, besides, some improvement in everyday life is necessary to alienate oneself from the past and to speak about it within a mutually shared framework (Gille 2010: 282).

A similar attitude towards things can also be traced among our other informants and their cultural texts. Through this mutual understanding of the material environment a certain distinction is drawn between the Soviet and post-Soviet worlds as well as between different generations: what they subjectively perceive as previous and subsequent. This is perhaps most explicitly expressed in the novel by Jan Kaus. One of its main characters Eda has found her son's broken toy in her pocket and is pondering on the art exhibition that she had recently visited. The latter was about things and the meaning of things in the past and today:

There is a generation growing up that has lost the ability to value things. This was an evaluation and, despite its outward politeness, a rather tough evaluation that separated generations from each other. Yet, Eda was not sure if this was what the artist wanted to say. The artist had been raised in Scandinavia. Eda, however, in a state where her peers did not leave broken legs of toy soldiers or dolls lying around, but did everything they could so that no leg would ever come off. (Kaus 2009: 41-42)

Another informant, Urmas, sees it even more dramatically, by describing Soviet identity through materiality and seeing the essence of this identity in procuring things. After our interview with him had ended and the dictaphone was switched off, Urmas announced that there was something important about Soviet time he yet had to tell us, and sitting back at the table he said practically in one breath: 
In short, it seems to me that I must also tell you about things of the Soviet time. It seems to me that - they say nowadays that all the people are very mammon-centred and so on, that they accumulate stuff, but it seems to me that it was way worse during the Soviet time. There was this same deficit back then, if something was lying around or available or there was a queue of some sort, then you had to take your place in this queue, no matter whether it was kvass or frankfurters or colour televisions. If there was some kind of a queue and it seemed that these things were not needed, they were nevertheless hoarded. [---] This kind of cult of things was absolutely total back then. And then things were stocked up, too. My grandmother had a wardrobe half full of sugar and flour, which was also scarce at a certain time. And buckwheat. Nobody knew what might start happening and if things would get even worse. My mother had stocked up pillowcases and doilies, like there are two sons and so they could both get something for their 'trousseau'. A line of thought that is totally absurd at present time. Most of these things were thrown away, there was nothing to do with them, but one had to hoard all the time. It is kind of like Imbi and Ärni stuff, this Soviet-era hoarding.

In the extract cited above, Urmas mixes together different stockpiling strategies - the need to stockpile food by those who had experienced scarcity during the war, and intergenerational traditional stockpiling of 'dowry chests', characterising them as a kind of 'gathering' through the characters known in Estonian contemporary literature - Imbi and $\ddot{A r n i}{ }^{15}$. It is also meaningful that things as a subject had emerged in his interview before discussing several topics of identity. Yet, he felt it important to come back to the topic of the material world from this 'procuring' perspective.

The visual side of the Soviet material environment is also strongly represented in the two films we chose. In the documentary Disco and Atomic War, more stress is laid on recreation of the lost space - especially the microcosm of one district in Tallinn - Õismäe. In the feature film Touched by the Unknown, visual details and artefacts, for example, clothing styles and interior design, become more prominent. This is part of the intention to play games with time, as will be shown in the following section. 


\subsection{Games with Time - Film Touched by the Unknown}

The feature film Touched by the Unknown ${ }^{16}$ is dedicated to the fiftieth anniversary of Estonian Television (ETV) and depicts life in television studios and beyond during late socialism, approximately at the end of the 1960s and beginning of the 1970s. Urmas Vadi was asked to write a script and Jaak Kilmi was invited to direct the film. As Jaak pointed out:

But all in all ... it doesn't actually talk about the ESSR [Estonian Soviet Socialist Republic] very much. It is something like ... like some kind of travesty, that these, well, the sixties, that there is such a ... more like an era of jazz, in principle, without any kind of real everyday aspect or political aspect.

Urmas told us in the interview that even though the era was set by order, he was also fascinated by it; ${ }^{17}$ otherwise he would not have taken the job. However, he stressed that for him the plot is always more important than the environment in which the story takes place. The film is a slapstick comedy with minor hints about historical events and characters. The latter are only loosely tied to their prototypes, since Urmas is fond of playing around with things:

Generally, to play out people's biographies...I have dealt with this previously, and probably will deal with it also in the future, but this is only one side of what I write. [...]

I don't remember exactly ... but in one philosophy lecture ... [...] the simplified idea was that a person is a sum of all that he/she has accomplished and done in their entire life, everything that you've done ten years ago and this all together is one life, and for me it seemed like an especially horrid thought, that everything is like it is, nothing can be changed and we live and exist ... and then I have been playing with the idea that actually you can change anything. That all people and documents can be written over and again. (Urmas)

Therefore, the entire scenario is built up playfully, emotions and situations have been exaggerated and, as Urmas himself put it, the text is 'baroque'. It is about a period in which none of the authors (neither the scenarist nor the director) have lived and their attitude towards this period is creative (to say the least). ${ }^{18}$ It is noteworthy that the restrictive side of the TV creating process (like censors) was not touched upon at all, and this has also attracted the critics' attention. Andres Laasik (2005) suggested in a review that instead of dealing with the political side of the era, the authors brought contemporary satire to the screen in the form of the 1960s ETV environment, since they had not been 
adults during the repressive Soviet period. Thus, Laasik (born in 1960) introduced the notion of generation: the birth date of the authors influences their attitude towards the Soviet period. This generational aspect was also touched upon by Urmas in our interview:

When ETV gave me an award, I attended the ceremony. There were no people of my age, so I quickly accepted this glass [the reward], stepped down from the stage and thought to myself: I have to get out of here as soon as I can.

Indeed, in the reception of the film, opinions were voiced that depicting famous TV-legends comically was insulting. ${ }^{19}$ As we will explore below, Vadi's playful treatment of characters and circumstances is rather cynical and ironic. See also Berdahl 2010: 130-133.

One of the central themes around which Urmas plays in the film is the notion of time. Time and its perception during the Soviet period are special in his treatment. Urmas is more than free in his mixing of different eras: even though the scene is set in the late $1960 \mathrm{~s}$, there are several hints at other eras: for instance, the aliens talk about Bill Gates and his Windows operating system. Instead of the contemporary First Secretary of the Estonian Communist Party (ECP) Johannes Käbin ${ }^{20}$, his successor from the future, Karl Vaino ${ }^{21}$, is presented in the film. This time mixing characterises Urmas's writing as a playful author, but there seems to be more to it. As stated, the course of time in the Soviet period is constructed as special, or at least different from contemporary society.

We were able to trace two main ways of depicting the time of the Soviet era among our respondents: time standing still and structured time, which are also present in the film. The category of time standing still is mainly constructed via the notion that nothing ever happens. When expressing their attitude towards working culture during the Soviet period, our informants rely on a common (negative) template that has recently spread about working life at that time. According to this, the pressure to be productive at work was not prevailing, so people did not do much at their workplaces and imitated work rather than actually worked. ${ }^{22}$ Most of the important decisions in the film are made in a smoky café where people sit (and drink alcohol) throughout their workdays. The waitress is depicted with a bored face, spending her time turning over the cheese on the sandwiches (time stands still even for the food, so when cheese gets too dry on the sandwich, it should be turned over). In his biographical interview Urmas recalls his own working experience in his early years as a blue-collar worker, suggesting that a significant amount of time was spent in the smoking room. Even though he did not smoke, he learned to play checkers at that time. ${ }^{23}$ This notion of negligent work experience is also reflected by other informants in 
their interviews. For instance, Kiur describes his childhood playground where some construction blocks had been left lying around for years:

Then we had this playground that we called the blocks [of concrete used in pre-fabricated buildings]. They were heaped into pyramids. In a former paddock. Obviously somebody had planned to build a house there, but had failed. A person dropped something from her/his hand, and there it stayed.

In addition to this negative stereotype of the Soviet working life, other informants supported Urmas's notion that there was enough time and the pace of time was slow. When talking about his childhood, Jan also indicated that there was not much one could do during the Soviet period: just collect chewing gum wrappers and play with tin soldiers. Karin described her childhood as calm and peaceful, appropriate for her poetic nature. One could go on with such examples. It is debatable whether their depiction of the Soviet era as slow and negligent owes some merit to the fact that during childhood time seems to pass slower. Time in this context is compared with the present, which is often perceived as fast, fractured and practical (Leccardi 2005). In any case, the informants described the Soviet era as the period where time was not a resource (but rather, social relations were). Things were often left undone, forgotten, abandoned, houses were left unbuilt.

The second category, structured or shared time, is also expressed in the film as well as in the interviews with other informants. In the film, time was structured by the TV shows that were loved by all. The figurativeness of this was drawn to the extreme - the film was interspersed with scenes in which virtually everyone left whatever they were doing and ran to sit in front of the TV. The lack of diversity in media production meant that people listened to the same programmes in media channels. This also expresses itself in several aspects in the interviews. One of the aspects of the Soviet period was that the structure of the programmes in those scarce media channels was similar throughout the years - the same broadcasts took place at the same hour for decades. Therefore, it is characteristic that the respondents rather remember what was on the radio during the time they left home or were driving in a car rather than what time it was:

Kiur: Dad would take me to school through snowdrifts in winter, and in the morning we would always listen to joke minutes, public radio had them after it had been declared that the 22nd regime of electricity consumption was in force that day or something like that, there on the car radio. There were these joke minutes, these were the brightest moments of the morning, because mornings were generally dark and cold and it sucked. ${ }^{24}$ 
Jaak: Did you listen to jokes in the car? I took off then, school started at 8 , jokes were on at 7:50 and then I took off.

In a similar vein, Kai remembers that they left for the countryside on Saturdays during a certain comedy broadcast on the radio. This notion of structure was indeed part of everyday Soviet life. However, the fact that this template comes up every now and then in the interviews may be influenced by the fact that it was the time of the informants' childhood. Childhood and school years consist of routines: time is structured by school time, hobby classes and vacations. In this sense, children today are not different from those born in the 1970s. The difference lies in the perception of time. Another aspect in the powerful structuring of time by audiovisual media was that there were certain shows that were important for people. A lot of what was broadcasted was not appreciated, but if something was worth watching, people organised their time accordingly (this is also evident from these quotes: all informants refer to comedy broadcasts). These factors indicate that TV and radio contributed to shared understanding and perception of time, probably during the Soviet era, but definitely they are significant symbols for this specific group about remembering the organisation of time. Time was shared - everyone remembers where he or she usually was during certain radio broadcasts, but also that nothing changed on the radio or in society in general. This is in contrast to fractured time perception now.

This phenomenon is also expressed in the cultural texts of the others. Jan, in his novel $A$ While, describes the TV shows that were broadcasted every New Year's Eve; in their exhibition, Karin and Kai show the standardised items that were similar in virtually every home; in their documentary, Jaak and Kiur describe the unifying effect of Finnish TV - it was important for all the family to see Dallas and introduce it to relatives outside Tallinn.

\subsection{Non-ideological everydayness: Novel $A$ While (2009)}

The novel $A$ While by Jan Kaus $(1971)^{25}$ focuses on two lives - Eda's and Joosep's. To use the author's own interpretation:

Well, it has always interested me, this, well, how to poeticise some very important things, the same ... When dreams do not come true, is dignified life still possible, a kind of reserved happiness and this started to interest me. (Jan)

Both Eda and Joosep had some dreams in their youth that failed to come true. In a way, this is a book about remembering and memory: ${ }^{26}$ both characters look back in time and ponder on the things that have happened, rather than 
are happening. The chapters have a rhythm, Eda's and Joosep's memories are presented separately, one following the other in every chapter. They had a love affair in the past and both reveal their versions of it. In addition, and what is crucial for our analysis, they contemplate their childhood during the Soviet period, their parents, the milieu of their childhood and the hometown (Tallinn) of their youth (remembrances of home-made food or romantic cityscapes). The author presents the time and space of their childhood and adolescence as lost (p. 22: "All these things are lost somewhere, or just lost."). There is a certain distinction between 'now' and 'then', the latter being a source of longing or nostalgia.

Coming back to the question of through what templates the late Soviet period is understood, we would argue that Joosep and Eda (and thus, in a way, Jan) represent those contributing to the discourse of 'normality', or those depicting the era as an exotic childhood experience. For them, the Soviet period is not "the interruption and deterioration of the harmonious national development" (Kõresaar 2005), but an environment where they spent their common childhood. The aforementioned is definitely not the restorative nostalgia according to Boym's (2002) definition, but, rather, the reflexive one: it helps us to understand the identity of the characters; it serves as the "meaning-making apparatus" (Misztal 2003: 13). However, the 'dark side' of the Soviet era coexists with the bright one in the story. Here and there, the author glances into the inhuman face of Soviet repressions through the stories of Joosep's uncle and grandfather. ${ }^{27}$ To summarise, in spite of some threats that the characters sense (expulsion from school after a party where alcohol was consumed), the repressive side of Soviet society is laid on the shoulders of their parents' and grandparents' generations. This disposition is very much connected to the time frame within which the authors of those cultural texts were born - the era of late socialism, where the repressive side of the Soviet system did not affect their lives directly. As Jan himself put it:

Well, childhood, as usual, is covered with powdered sugar. [...] I don't have this depression about the Soviet period, it didn't reach me. My childhood is rather grey. I don't have any colourful impressions - neither negative nor positive.

Yet, Jan was the only one of the six interviewees (he was also the oldest) who actually had had a personal experience of repression and interrogation by the $\mathrm{KGB}$, for owning graffiti paints ${ }^{28}$. He admits that he has vague memories of this episode but claims that, being naïve and young, he did not grasp the seriousness of the situation. Our informants just did not function in the adult world, and ignored the 'bad' sides because their parents had to deal with them: 
Karin: [...] like ... you accept these circumstances. Whether you have Brezhnev there or not, you didn't take notice of it.

Kai: But you didn't have to accept the circumstances yourself, it was your mother and father who had to accept them. It was like ... I think, it didn't raise a problem in a child.

Karin: It always exists, but in a sense you, you have been taught this pattern of behaviour, whereby you skip border zones for instance [...] In everyday life, you have some ways of functioning. Islands of private life, you go to the woods and enjoy picking berries.

Another reason for not depicting the system as a repressive and occupational regime was probably that the parents, lacking the experience of an independent republic themselves ('the golden age'), did not want to 'tune' their children against the system because describing the Soviet system as restrictive could bring problems. Their parents had mostly spent their youths in the thaw or stagnation time, when one's course of life was not usually affected by repressions. Urmas mentions keeping silent about the past issues in intergenerational communication:

Yes, it was not talked about. I guess people were still afraid. Who knows what some kid says somewhere in school, probably it's for the best this way. Nothing of the sort, like once upon a time there was the Republic of Estonia, our own currency, or anything like that. [...] In short, they didn't talk and this was out of fear. What's the point of telling a small 10-year-old boy, he wouldn't understand anyway. [...] I lived at the end of the Soviet period when the whole thing wasn't that tough and brutal and terrifying ... [...] I would like to know further what this time was like. And at the same time I cannot help it that for me, it wasn't the time of executions and deportations. In this sense it was a colourful dumb time where many things were possible.

However, as most of the interviewees admitted, the tacit attitude towards the state and, thence, also to Russians, was negative. Yet, it was unspoken and unspecified. While this situation was also common in other families, Jaak had a different experience:

As concerns the worldview of a child back then, a lot of it was shaped by my father, who was a passive dissident. He despised Soviet power with every cell in his body. This attitude is very easily adopted by a child. I always took it very tragically when a Russian athlete made it to the podium. 
He spoke about how he outlined the flags of Soviet-friendly states in his scrapbook with 'poop' colour and how he, with other boys at school, filled the eyes of Lenin's sculpture with green candies. He also refused to join the pioneer organisation, but was persuaded to reconsider his decision. He joined the organisation a few months after his classmates had. While his hatred for Soviet powers was sincere, it was still the hatred of a child, who translated this into his language of 'good/evil': outlining the socialist states' flags with ugly colours or being disappointed at the outcome of sporting events. In everyday life, he still enjoyed living in a new block-house district called Õismäe and expresses nostalgia for this period.

To conclude, for the characters of the book, and our authors, memories of the Soviet period are childhood memories, which are nostalgic for personal reasons. During their adolescence and transition to adulthood, when our informants started to take independent decisions about their adult lives, the system was in the midst of its most turbulent changes. For Eda and Joosep, these changes raised hopes for their future lives, but the hopes gradually petered out for several reasons, which was mainly something to do with their personal lives. Yet, the 'now' in the book, the independent state, is covered with the same veil of disappointment and bitterness. Although this distinction between the hopeless present and the hopeful and nostalgic past is vivid in the book, it is not something we could track down in our interviews. The interviewees shared a certain nostalgic attitude towards their childhoods and some of the values that were dominant at that time and are now lost, but there was no longing for its ideological side or attempts to legitimise the Soviet system.

\subsection{Making of a generation? Ironic understanding of history -}

\section{Documentary Disco and Atomic War (2009)}

In the documentary Disco and Atomic War the central role is played by Finnish television (FTV) and its impact on the course of the Cold War and on those born in the 1970s. The film presents chapters in recent Estonian history in a carnivalesque key (Bahktin 1993). The authors - Jaak Kilmi (1973) and Kiur Aarma (1974) - point out in their interview that the film is indeed playful, but it is also based on the personal experience of the two authors.

This film is purely born of self-cognition. All things have been kind of derived from personal mythology. (Jaak) 
The film unites two interconnected narratives, one of them being the history of FTV ${ }^{29}$ in the context of Cold War discourse. In this sense, it is closely tied to the dominant official memory discourse in the Soviet period. In order to exemplify this, abundant authentic archival film material is used: shots of the Soviet invasion in Prague in 1968, of parades held on May 1st, the head of the party laying wreaths at war memorials. In addition, several expert interviews are used to support the treatment of history offered in the film. The framing narrative tells the story of FTV as soft power that has beaten Soviet ideology. In the film, the French erotic film Emmanuelle is presented as the final victorious medium winning the Cold War. The scene showing its debut on FTV is followed by a scene presenting Estonians singing about freedom in a night song festival ${ }^{30}$ in 1988.

Another narrative in the film - the one that is closely tied to the personal experiences of our informants - has the entertaining side of television as its focus. The film shows how the broadcasts and films shown on FTV were part of children's/youngster's everyday lives. For the informants grown up in northern Estonia, FTV is part of their shared experience, also forming a category that is used to distinguish themselves primarily from younger generations:

There are some things [distinguishing those born in the 1970s from the others]. I do talk with Finns [in Finnish]. ${ }^{31}$ I define myself as a Pikku Kakkonen $^{32}$-person through Finnish children programmes. I owe my Finnish to Finnish children shows. Even today, I am a Finnophile deep down. (Karin)

Or, as Jan has put it, the "real" Christmas feeling during the Soviet time was mediated through FTV, something that is lost in the contemporary world.

Definitely this Finnish Television was important in my childhood. I have thought about the Christmas feeling ... During the last ten years I have been trying to recreate this feeling, but it does not work, perhaps because I do not see this Christmas calendar [show] on Finnish television. (Jan)

As mentioned above, original historical material is incorporated into the documentary, and this integration of photographic (authentic photographs, bleak colours, black-and-white photographs) and filmic media creates an effet de réel (Erll 2008: 394). Binding a fictional story with facts is not a technique characteristic only of this film. In this respect, Urmas Vadi's Touched by the Unknown can be pointed out as well, with historical people acting in a real space (television, Tallinn), though the plot is fictional. In addition, in Jan Kaus's $A$ While the urban space of Tallinn is described in detail and the book is very documental, though the characters and the plot are semi-fictional. In Disco 
and Atomic War actual events are intertwined with fictional characters, who are presented through convincing voices speaking in the first person. It is noteworthy that sometimes it becomes difficult even for the authors to make a distinction between the fictional actuality and the 'actual' actuality, indicating that for them fantasy has transformed into memory at some point:

Jaak: We had to build up most characters in our heads, use this clay that was sent to us. ${ }^{33}$ By people, by nice people who took the effort to write to us [about their memories]. We had to fill these holes [that emerged] dramaturgically, by making up humorous things. Like the episode where boys were talking to foreign cars via their electronic watches. ${ }^{34}$

Kiur: It was one of my classmates who did this.

Jaak: Was it indeed? I remember the contrary ... I thought that I made it up. No, I do remember that after we had finished the film, somebody came and told us that he used to do this. OK, at least it was not sent to us along with memories.

One of the authors has explained this usage of different audio-visual materials as a form of carnivalism. Kilmi has argued in an interview to a cultural magazine that, 'consuming' FTV can be explored as a carnivalistic rebellion against the system (Teder 2009; on carnevalistic rebellion see also Paju \& Võsu 2008).

The film can also be located in space. The authors use a number of pictures and archival shots of one of the residential districts of Tallinn - Õismäe, where both authors grew up. In the reception, the film has also been interpreted as a documentary about Õismäe (Keil 2009) ${ }^{35}$. Jaak himself indicates that this can be one of the possible keys to interpreting the film. He dedicates the first minutes of his biographical interview to Õismäe, bringing out the special position of the residential district in Soviet society: "Of course, it felt proud to live there. Like, the small elite of the ESSR lived in Õismäe," showing us the pictures his father had taken over the decades from their apartment window (the same photos were also used in the film). The world shown in the film, however, is lost: while reminiscing about this lost time, Jaak acknowledges that the space has been lost with it. The lived space of the late Soviet period - childhood Tallinn ${ }^{36}-$ is gradually evaporating. It has been either rebuilt, 'built in' or just torn down.

I have kind of come to understand that there is no escape from Õismäe. Disco and Atomic War was also very much a film about Õismäe, it just has to be let back into the consciousness, but then through the humour prism, through jolly dislocation. [---] For me, Õismäe [now] is like a joke. In addition, it is so ugly, slummified, all the balconies have been rebuilt, 
buildings are covered with corrugated metal sheets or EPS. And mainly elderly Russian pensioners live there. It is not a stimulating place - in no way. (Jaak)

Similar reflexive nostalgia towards lost space can also be explored in Jan's interview, where he describes how his immediate surroundings have changed over time. He has also used his childhood spatial environment in his books. For instance, in A While an entire chapter is dedicated to Tallinn and what it used to be like. In contrast to Jaak and Kiur's 'elite' district, for Jan the lost space is represented by a slurb.

Actually I feel sorry that this Tallinn of my childhood is practically disappearing, all this tearing down [---] On the city side of the railway, there were several beautiful functionalist structures built in the 1930s. There was one communal sauna where we used to go with the entire family. There was another building that had a huge picture of Brezhnev on the wall ... This was torn down and ... The surroundings changed to the point of becoming unrecognisable. (Jan)

In addition to this, the openness of the slurbs and suburbs that has disappeared is pointed out. The children of today are perceived as no longer playing in backyards; the environment enabling social interaction is lost ("backyards, all of them that have been closed up today" (Karin)).

The film also aims to depict the experiences of this generation in Soviet Estonia, thus giving the childhood experience of the authors a broader meaning. Jaak Kilmi has stated that they didn't want to make a documentary only about Finnish television, but much more - about their generation against the backdrop of this television (Teder 2009). In addition to FTV, the First Secretary of the ECP, Karl Vaino, who appears at the parade on May 1, but also at a song festival (on rituals, see also Grünberg 2008), is an important figure in this film. His frequent appearance could be interpreted as a hint at the Soviet ideology, which in a way shaped the childhood of those born in the 1970s. He has become the symbol of this ideology and is described in the film by Kilmi and Aarma as the "symbol of silly life in Soviet Estonia". ${ }^{37}$

Even though, judging by the interviews, the impact of kindred spirits and relatives on one's identity is considered important, the mutual experience of those born in the 1970s is also considered essential in distinguishing them from those born later on. In addition to the mutual media consumption, another aspect can be elicited from the interviews: the ironic attitude towards the past as well as present. For instance, Kai expresses her condemnation of the new 
wave of nationalism that arose at the beginning of the 21st century. In this sense the experience of the Soviet period has given to our informants the ability not to get carried away by different ideological outbursts.

When they were erecting the monument of liberty ${ }^{38}$, I remember talking with somebody about it, and then this generational topic came up, those who designed it, they designed such a thing, they are a generation back from us [emphasis added]. I do not know what the age difference between us is, maybe five or ten years. This is surprising that they do such a thing, this has moved around in such a circle. Damn it. Where was this coming from? (Kai)

Thus, once again, we can come back to ironic and cynical nostalgia. In the case of this particular documentary, it may even be hidden: the documentary format, archival shots and expert interviews represent the 'serious' discourse, that which supports the official memory policy, the discourse of rupture. At the same time, the staged scenes are at times comic, the characters vivid and even caricatural. In other words, irony is mixed with the 'grand narrative'. As we will show in our concluding section, this can be one of the discursive practices that is characteristic of those born in the 1970s.

\section{DISCUSSION AND CONCLUSION: PAST IN THE MAKING?}

Reception plays a vital role in a cultural text becoming part of cultural memory. Reception is the context in which the text is produced. In our case, the context is a gradually growing boom of nostalgia (2000-2010) for the late Soviet period. As Ann Rigney (2008: 347) has stated, cultural texts draw attention to certain topics (in our case, the Soviet era) by offering a good surrounding story, even without a prior interest in the subject. Texts that are more spellbinding have the potential to influence cultural memory more, in contrast with those that aim for a more realistic picture (like, for instance, Tolstoy's War and Peace; ibid.). Cultural texts can deal with topics and eras that the official memory discourse is reluctant to take up. Even though in our case it is difficult to predict what the position of our texts could be in the future, we believe that the texts have potential to have a broader impact on memory culture. In addition, as these authors are active in the cultural field and have continued producing cultural texts, we assume that their biographical background and construction of the Soviet past influences their other texts as well. In this sense, these specific 
texts can be treated as examples of their reproduction of the Soviet past and the conclusions can be drawn on a broader cultural ground.

We have already briefly indicated the possible impact of the analysed exhibition. After this one, several others have been opened dealing with the presentation of everyday Soviet life. The question of whether these exhibitions were inspired (and to what extent) by the Things in My Life is debatable. Yet, they were the first. Kai has been active in curating other exhibitions that are based on Soviet design. In 2011, she was a curator of an exhibition that presented the design of lamps from one factory during the late Soviet era. In 2012 an international exhibition, Modernisation. Baltic Art, Architecture and Design in the 1960s-1970s, opened at the Estonian Museum for Applied Art and Design, where the Estonian part was curated by Kai.

Reception of the exhibitions, however, no longer brought up the topic of ideology. Karin is teaching the history of design at the Estonian Academy of Art and has been active as a contributor to several cultural periodicals; recently she published a book about the history of design, with the subtitle 'Things in my life' (Paulus 2011).

Today, the feature film Touched by the Unknown is not perhaps a film very widely known or often shown on TV. However, Urmas Vadi as a playwright and writer is creatively active. In his last book Letters to Aunt Anne (2010), he also brought up the topic of childhood during the late Soviet period, treating it along similar lines to the templates we have pointed out in our analysis. Hence, we must observe Vadi's potential role in creating cultural memory in a broader context, taking into account his creation in its entirety.

Jan Kaus's novel $A$ While probably has a limited audience of intellectual elites. However, it was one of the four nominees for the 2009 annual Cultural Endowment of Estonia award (the most prominent literature award in Estonia) and thus one of the influential books in contemporary Estonian literature. Jan is a well-known figure in cultural life apart from being a writer. He was the chairman of the Estonian Writers' Union (2004-2007) and also an editor and contributor to the most influential cultural newspaper Sirp, as well as being a well-known translator. Therefore, his attitude towards late Soviet society is something that could possibly have a wider audience than just the readers of his book.

The documentary Disco and Atomic War, in contrast, has the widest audience among the selected cultural texts. In addition to Estonian film festivals, it has been presented internationally and has won several awards in Europe. Yet, its impact is hard to estimate, since much of its reception probably depends on how the experience of the audience coincides with that of the film authors. The 
irony and cynicism presented might be hard to grasp for an outsider. Thus, it probably still helps to deepen the discursive practices among those who share the same templates, while having a different impact on those who do not share them. Jaak and Kiur continue to produce films together. Commenting on their recent film, released in 2011 (Tallinn Spiced Sprats: the Canned Tales), Jaak Kilmi, in his interview to a daily newspaper commenting on the film, mentioned the ambition to bring in the generational prism of his age group as well as living in Õismäe (Laasik 2011). This indicates that the biographical base we have presented continues to have an impact on their creative work.

As our analysis has shown, the border between cultural and communicative memory is vague. The potential to live through the abyss of time, as the Assmans have indicated, is unknown in all the texts. Yet, they are part of contemporary 'high' culture, as they are produced within the framework of an official cultural establishment (they are either presented in official state museums, ordered by national television or are award-winning texts). At the same time, they reproduce the discursive practices that are part of the authors' lives and are closely related to their everyday life discourses, i.e., communicative memory. In other words, the border between the two is shifting and blurry. However, in terms of analytical purposes it may still be useful to distinguish them over a longer time perspective. As indicated above, the texts 'speak' in the language of communicative memory with those sharing the same experience. For future generations, though (if these texts continue to be part of cultural memory or these authors continue reproducing their late Soviet experience), the communicative part will gradually fade away and the texts shift to the category of cultural memory where they can be reinterpreted by generations to come.

The discursive practices that we have attempted to detect among our informants can be (to a certain extent) interpreted as generational. Generational consciousness is a sensible topic, and it is noteworthy that not all our informants were eager to draw clear generational lines and admit that understanding the past depends on their birth date. Yet, following the reception and critique of the texts, certain understandings of the past emerge that are contextual and seem to be age-specific. In addition, on the basis of the life stories and their selfreflexive interpretations one can assume that the absence of harsh repressive experience due to their age and the era (late Soviet period) had an impact on their perspective on the interpretation of the era.

In the following, we will briefly go over the main templates that we find to characterise these authors' works as well as biographical narratives. The absence of repressive experience and growing up in an environment where the issues of the past (especially those connected to the pre-war independence 
and its loss) were rarely communicated, is something that we believe has contributed to the informants' support for 'normalisation' discourse on the Soviet era. They mainly concentrate on everyday experience, and at times add a jolly accent of irony and cynicism. At the same time, they do not seem to actively oppose the general public narrative of rupture and disdain for Soviet ideology, and at times even contribute to it.

This also means that the nostalgia that is vivid in the authors' cultural texts as well as in their interviews can have many faces that do not necessarily contradict each other (cf. Kõresaar 2008: 761, several nostalgias can coexist). Thus, nostalgia for the Soviet era does not mean yearning for Soviet order (restorative nostalgia in Boym's sense). Rather, our informants express a certain reflexive nostalgia: a longing for the calm and structured childhood with certain characteristics that are lost in the contemporary world. Even the absence of things is sometimes interpreted in a positive light: people valued things more and thus avoided the carelessness of the contemporary consumer society. While some things are missed for the value that has been lost, others are missed because of their absurdity. The latter nostalgia is expressed in cynical and ironic form. The presentation of such things does not necessarily mean that these things are valued deep down; however, they represent a certain type of humour that can sometimes be understood only by those sharing the experiences gained from that time.

Remembering the past makes us what we are today. As we have shown in the current paper, the late Soviet experiences of their childhood are an integral part of those intellectuals' identities. By reproducing those discursive practices that form the base of their identity, they have the potential to deepen the memory templates already existing in public memory discourse, and also contribute to adding new ones and influencing the identity of the others in society.

\section{ACKNOWLEDGMENTS}

The preparation of the article was supported by the Estonian Science Foundation grants No. 8190 and 9130, and by the European Union through its European Regional Development Fund (Centre of Excellence in Cultural Theory, CECT). 


\section{NOTES}

1 On the meaning of 'late' or 'mature' socialism in Estonian memory culture see Jõesalu \& Kõresaar 2013 (forthcoming); Jõesalu 2010.

2 "In a common attempt to remember the past, social groups can and frequently will encounter differences of temporal horizon or differences in focusing on special events as turning points of history. Events that have a key importance for the collective memory of one group may be ignored or omitted in the collective memory of others and even if both agree to attribute crucial importance to a particular event they still can greatly diverge in their interpretation of it." (Giesen 2004, p. 32).

${ }^{3}$ For a deeper analysis of nostalgia in Estonian post-Soviet memory culture, see Ene Kõresaar (Kõresaar 2008).

4 Ostalgie - nostalgia for the East ('Ost' in German), the notion is used when speaking about nostalgia processes in the former GDR.

5 As one of the authors has closely studied self-understanding in the 1970 s, we can use the interviews conducted with the people born in the same timeframe as backdrop data to position the cultural texts and the interviews with their authors on a broader scale (Nugin 2011).

6 In terms of self-reflexive analysis, we find it important to mention that we share the birth frame of the informants, being both born in the mid-1970s.

7 A rural background was thematised in the interviews only by Urmas, who spoke about his living and working experience in the countryside. However, the perspective on rural contexts is still the one of an urban child.

8 The notion of template is used in different disciplines and its use overlaps in practice. In this article we depart from memory studies, relying on the work of James Wertsch (Wertsch 2002).

9 In the Soviet period Karin's father worked as a seaman. Part of the salary was paid in vouchers and for these they could obtain some goods from special shops.

10 The exhibition was first presented in Tartu (December 2000 to February 2001) at the Estonian National Museum. Kai and Karin filled in the application to exhibit it at the National Museum, since they found that it would be 'safer' to present it in Tartu than in the capital, in front of the cultural elite. The exhibition in Tallinn stayed open from April to June, 2001, and it took place at the Museum of Applied Art, at which Kai works to this day.

${ }^{11}$ Before this exhibition, no exhibition had focused on everyday Soviet life. However, some exhibitions may have had hints of it among other things. Such an example is the exhibition about spirit smuggling in Estonia through ages exhibited in one of the county museums in 1998-99. After the exhibition that we have dealt with here, several others dedicated to everyday Soviet life followed, staged at the Estonian National Museum in 2004, 2006 and 2007 (Jõesalu \& Kõresaar forthcoming). At the end of the decade life in the Soviet era was also presented in other places, representing the 'lost' 
and exotic side of the everyday (e.g. an exhibition in Rotermann quarter in Tallinn: Soviet Life, www.rotermannikvartal.ee).

${ }^{12}$ One of the authors visited the exhibition. However, it is hard to build up an analysis on experience dating back a decade. In addition, no notes were taken. Artefacts were exhibited mainly on shelves. In the exhibition hall, the so-called coffee corners were built using Soviet-period furniture.

${ }^{13}$ A small bed lamp in the shape of a lantern with the symbol of Old Thomas. Old Thomas is a weather vane that was put on top of the spire of Tallinn Town Hall in 1530.

${ }^{14}$ From the same art historian, the curators got a personal disappointed note saying that the things exhibited were too ugly. Misinterpretation of the past is an accusation that has also hit other authors; Astrid Lepa (b. 1924), for instance, felt insulted by the way Urmas Vadi had treated the past in the film Touched by the Unknown.

15 The characters are taken from the book Rehepapp (Old Barny), in which the author Andrus Kivirähk (b. 1970) aims to describe Estonian rural community under the domination of the Baltic-German gentry, though the exact time period is not explicitly stated. Some of the characters in the book are taken from Estonian mythology. Imbi and Ärni represent a couple who go around with two large bags, trying to steal everything they can, regardless of whether they need these things or not (Kivirähk 2000).

16 The action of the film takes place in 1969. The main character Mati Tilba works in ETV in minor assisting roles, but everything seems to go wrong in his work as well as his private life. Mati works together with a TV legend Valdo Pant (a historical character, most beloved by his contemporaries, his main show was about the Great Patriotic War). Suddenly, the lives of those in ETV are interrupted by an alien from Mars, who comes to explore why the characters in a famous children's show (Tipp and Täpp) look similar to the inhabitants of Mars. The alien chooses Mati Tilba as his partner on Earth and lives in his head. When Valdo Pant takes too many pills with alcohol and becomes paralysed, Mati Tilba takes his place and with the help of the alien becomes another beloved figure in TV shows. He then changes his name and becomes Mati Talvik. The latter is also a historical character and a famous leader of TV talkshows, whose most popular years on TV were after Valdo Pant had died.

17 Some of Vadi's other texts also deal with late Soviet period, e.g. Human, Play and Georg (Vadi 2008).

${ }^{18}$ In the short documentary about making the film, Jaak Kilmi starts his interview with the words: "I was born in 1973. I remember nothing."

${ }^{19}$ For instance, in the interview in the documentary about making the film, Astrid Lepa (born 1924) expressed her disappointment. Other cultural texts dealing with the Soviet period playfully have received similar receptions (e.g. Grünberg 2008).

${ }^{20}$ First Secretary 1950-1978.

${ }^{21}$ First Secretary 1978-1988. 
22 This can be another source of generational distinction. Those who were born earlier and had active working lives during the Soviet period do not reflect this category in their life writing. On the contrary, they rather value their work contribution highly and oppose the notion of little work (see Jõesalu 2005).

${ }^{23}$ It is significant that Urmas presents his working experience in the frame of the Soviet era. Considering his birth date, it should have been at the beginning of the 1990s, in other words, after the Soviet Union had collapsed. This mixing of eras (attributing some traits or events that happened after the Soviet Union to late socialism) can sometimes be seen by other respondents.

${ }^{24}$ During the 1990s, it was quite common in life writing to describe the Soviet period as a cold and dark era. Kiur characterises this period as a dark time in another context in the interview as well: "February 24 of the same year [Independence Day in 1988] was rather dark, you see, it was a very cold day, and then there had been prohibitions and warnings [against attending a public meeting demanding the restoration of the independent Estonian republic]."

${ }^{25}$ Eda had been a promising young painter, Joosep studied theology. They met in a band where Eda was a solo singer and Joosep a dancer. Their affair was broken by Eda's unexpected pregnancy and Joosep's reluctance to accept the decision to have a child. Eda had an abortion and after Joosep was gone, she had an affair for years with a married man. She got pregnant again and gave birth to her son Jakob, making a conscious decision to become a single parent. Her life seemed to have reached a dead end, with a shaky relationship and no steady job (she was gradually loosing her interest in painting). Joosep ended up as a taxi driver as was his father, pondering on his lost life while driving around in the city. While most of the novel is built up in a somewhat pessimistic tone, the last part changes - it offers the reader what looks like a prologue: Eda has given up the idea of becoming an artist and has become a midwife. She helps Joosep and his new wife to give birth to their first child. Eda herself has ended her relationship with the married man and is living together with another member of the band in which she met Joosep. While they both admit to themselves that they had been the only true loves in their lives, they have found a way to their own quiet happiness.

${ }^{26}$ The importance of remembering has been brought up in the reception, too. For instance, Johanna Ross (2010) states that both characters mainly deal with remembering and are yearning for the past.

${ }^{27}$ It is noteworthy, though, that the chapter entitled Package, where Joosep's grandfather's story is told, was criticised in its reception, as it seemed to the reviewer to be artificial and not concomitant with the overall tone of the book. The reviewer, Johanna Ross (b. 1985), pointed out: "Actually the book is not missing [--] dark, confusing, secretive and baleful groping in the past, which is brought in, as usual, by elderly generations. While mother's recollections melt organically into the story, the chapter entitled Package - grandfather's story on the tape - seems to be a violent and clichéd addition (Ross 2010). The aspect that the author does not depict convincingly the repressive side of the Soviet past (rupture discourse) allows one to speculate that it is not an organic side of the author's identity either. 
${ }^{28}$ One of the roles of the KGB was also to guard over 'public order', and graffiti symbolised the Western way of life, which did not fit in the Soviet public space.

${ }^{29}$ Finnish Television here refers to different Finnish channels.

30 The Night Song Festival is a series of events in which people gather at the Song Festival Grounds in Tallinn and sing patriotic songs throughout the night to show their political commitment.

${ }^{31}$ Estonian and Finnish belong to the Finno-Ugric language group and are similar to a certain extent. Thus, those watching FTV picked up the language by watching TV.

${ }^{32}$ A Finnish children's show.

${ }^{33}$ Before writing the script, the authors made an appeal for recollections about Finnish Television in everyday life, the announcement for which was published in the daily Postimees in 2006. See: http://ooper.postimees.ee/100306/esileht/meedia/194508.php.

${ }^{34}$ An allusion to the film Knight Rider, in which the main character gave orders to his car via an apparatus fastened to his wrist like a watch.

${ }^{35}$ Andres Keil, the author of the review, also grew up in Õismäe.

${ }^{36}$ The topic of lost space did not emerge in Urmas's interview when discussing Tartu. Yet, he described rural space in a somewhat similar manner, talking about times when there was a vivacious social life as opposed to the abandoned rurality of today.

37 "And so, here's our generation marching in front of the cameras, with paper flowers and Estonian folk costumes." "Here [The Song Festival in 1985] our generation runs to the stage with flowers to Karl Vaino."

${ }^{38}$ A statue that was erected after long discussions in 2009. The draft that won the competition was held by several intellectual circles as too conservative and old fashioned, since it was similarly designed to the statues built in the $1930 \mathrm{~s}$, during the right wing dictatorial regime in Estonia. The statue is in the shape of large cross. The four authors of the draft, however, were born in the 1980s.

\section{MANUSCRIPT SOURCES}

Guestbook of the Estonian National Museum 2006.

Interviews in the possession of the authors. 


\section{REFERENCES}

Aarelaid-Tart, Aili 2006. Cultural Trauma and Life Stories. Helsinki: Kikimora Publications.

Aarma, Kiur \& Kilmi, Jaak 2009. Disko ja tuumasõda. [Disco and Atomic War.] DVD. Eetriüksus, 78 min.

Anepaio, Terje 2003. Eesti mäletab!? Repressiooniteema retseptsioon Eesti ühiskonnas.

[Estonia remembers!? Reception of the repression topic in Estonian society.] In:

E. Kõresaar \& T. Anepaio (eds.) Mälu kui kultuuritegur: etnoloogilisi perspektiive.

[Ethnological Perspectives on Memory.] Studia Ethnologica Tartuensia 6. Tartu:

Tartu Ülikooli Kirjastus, pp. 206-230.

Assmann, Aleida 1999. Erinnerungsräume. München: C.H. Beck.

Assmann, Aleida 2006. Der lange Schatten der Vergangenheit. Erinnerungskultur und Geschichtspolitik. München: C.H. Beck.

Assmann, Jan 1995. Collective Memory and Cultural Identity. In: New German Critique, No. 65, Cultural History/Cultural Studies (Spring - Summer, 1995), pp. 125-133.

Assmann, Jan 2008. Communicative and Cultural Memory. In: A. Erll \& A. Nünning (eds.) Cultural Memory Studies. An International and Interdisciplinary Handbook. Berlin \& New York: Walter de Gruyter, pp. 109-118.

Bakhtin, Mikhail 1993. Rabelais and His World. Bloomington: Indiana University Press. Berdhal, Daphne 2010. On the Social Life of Postsocialism. M. Bunzl (ed.). Bloomington: Indiana University Press.

Boym, Svetlana 2002. The Future of Nostalgia. New York: Basic Books.

Corsten, Michael 1999. The Time of Generations. Time \& Society, Vol. 8, No. 2, pp. 249-272, doi:10.1177/0961463X99008002003.

Erll, Astrid 2005. Kollektives Gedächtnis und Erinnerungskulturen. Stuttgart: Verlag J.B. Metzler.

Erll, Astrid 2008. Literature, Film, and the Mediality of Cultural Memory. In: A. Erll \& A. Nünning (eds.) Cultural Memory Studies. An International and Interdisciplinary Handbook. Berlin \& New York: Walter de Gruyter, pp. 389-398.

Giesen, Bernhard 2004. Noncontemporaneity, asynchronicity and divided memories. Time \& Society, Vol. 13, No. 1, pp. 27-40, doi:10.1177/0961463X04040741.

Gille, Zsuzsa 2010. Postscript. In: M. Todorova \& Z. Gille (eds.) Post-Communist Nostalgia. New York: Berghahn Books.

Grünberg, Kristi 2008. Andrus Kivirähki / Taago Tubina lavastus "Helesinine vagun" (2003) - sissevaade vene multikate põlvkonna hinge? [Stageplay by Andrus Kivirähk / Taago Tubin "Blue Wagon" (2003) - an insight into the soul of Russian cartoon generation?] Eesti Rahva Muuseumi Aastaraamat [Yearbook of Estonian National Museum]. Tartu: Eesti Rahva Muuseum, pp. 13-46.

Hinrikus, Rutt 2005. Estnische Lebensbeschreibugen 1939-1953: erzählte Realität. In: O. Mertelsmann (ed.) Vom Hitler-Stalin-Pakt bis zu Stalins Tod: Estland 1939-1953. Hamburg: Bibliotheca Baltica, pp. 183-210.

Jõesalu, Kirsti 2005. The Right to Happiness: Echoes of Soviet Ideology in Biographical Narratives. Berliner Ostereuropa Info, Vol. 23, pp. 91-99. http://www.oei. 
fu-berlin.de/media/publikationen/boi/boi_23/11_joesalu.pdf, last accessed on 4 December 2011.

Jõesalu, Kirsti 2010. The Meaning of "Late Socialism": Analyzing Estonians' PostCommunist Memory Culture. Asia Europe Journal, Vol. 8, No. 3, pp. 293-303, doi:10.1007/s10308-010-0269-4.

Jõesalu, Kirsti 2012. The Role of the Soviet Past in Post-Soviet Memory Politics through Examples of Speeches from Estonian Presidents. Europe-Asia Studies, Vol. 64, No. 6, pp. 1007-1032, doi:10.1080/09668136.2012.691723.

Jõesalu, Kirsti \& Kõresaar, Ene (forthcoming in 2013). Continuity or Discontinuity: On the Dynamics of Remembering "Mature Socialism" in Estonian Post-Soviet Remembrance Culture. In: Aet Annist (ed.) Journal of Baltic Studies. Special Issue. Temporality, identity and change: Etnographic insights into Estonian fieldsites, Vol 44, No. 1.

Kaus, Jan. 2009. Hetk. [A While.] Tallinn: Tuum.

Keil, Andres 2009. Diskost ja tuumasõjast. Elu on pohmakas. [About disco and atomic war. Life is a hangover.] In: Kes.Kus.5. http://www.kes-kus.ee/index.php?katego oria=artiklid\&action=loe\&artikkel_id=2239, last accessed on 4 December 2011.

Kirchenblatt-Gimblet, Barbara 1989. Obejcts of Memory: Material Culture as Life Review. In: Elliot Oring (ed.) Folk Groups and Folklore Genres. A Reader. Logan: Utah State University Press, pp. 278-285.

Kivirähk, Andres 2000. Rehepapp ehk November. [Old Barney or November.] Tallinn: Varrak.

Kuma, Helene 2001. Kiri toimetusele. [A letter to Editor.] Postimees, April 21.

Kõresaar, Ene 1998. Vital things. Objects in life histories, life histories in objects. Pro Ethnologia 6, pp. 29-40.

Kõresaar, Ene 2005. Elu ideoloogiad: kollektiivne mälu ja autobiograafiline minevikutõlgendus eestlaste elulugudes. [Ideologies of life: collective memory and autobiographical interpretation of the past in Estonians life-stories.] Tartu: Eesti Rahva Muuseum.

Kõresaar, Ene 2008. Nostalgia ja selle puudumine eestlaste mälukultuuris: eluloouurija vaatepunkt. [Nostalgia and its Absence in Estonians' Memory Culture. The View of a Biography Researcher.] Keel ja Kirjandus, No. 10, pp. 760-771.

Kõresaar, Ene \& Kuutma, Kristin \& Lauk, Epp (eds.) 2009. The Burden of Remembering: Recollections and Representations of the Twentieth Century. Helsinki: Suomalaisen Kirjallisuuden Seura.

Kõresaar, Ene (ed.) 2011. Soldiers of memory: World War II and its aftermath in Estonian post-Soviet life stories. New York \& Amsterdam: Rodopi.

Laar, Mart 2008. Kommunismi kuriteod ja meie. [Communist Crimes and Us.] Diplomaatia No. 60, August. http://www.diplomaatia.ee/index.php?id=242\&tx_ ttnews\%5Btt_news\%5D=520\&tx_ttnews\%5BbackPid\%5D=429\&cHash=398a1 e4a1e, last accessed on 4 December 2011.

Laasik, Andres 2005. Kuuekümnendate telemaja pakub täna nalja. [The Television Building of the 1960s Offers a Good Laugh Today.] Eesti Päevaleht, January 
3. http://www.epl.ee/news/kultuur/kuuekumnendate-telemaja-pakub-tananalja.d?id=51000561, last accessed on 4 December 2011.

Laasik, Andres 2011. Linnalegendid tänapäevasest ja keskajast. [City Legends Today and in Middle Ages.] Eesti Päevaleht, July 30, pp. 8-9.

Leccardi, Carmen 2005. Facing Uncertainty. Temporality and Biographies in the New Century. Young, Vol. 2, No. 13, pp. 123-46, doi: 10.1177/1103308805051317.

Lobjakas, Kai \& Paulus, Karin 2000. Postuumselt rehabiliteeritud?: näitus 'Asjad minu elus. Nõukogude Eesti tootedisain’ Eesti Rahva Muuseumis 12.12.20004.02.2001. [Posthumously rehabilitated: exhibition 'Things in my Life. Industrial Design of Soviet Estonia'.] Maja 4, p. 9.

Mannheim, Karl 1993 [1952]. The Problem of Generations. In: M. A. Hardy (ed.) Studying Aging and Social Change. Conceptual and Methodological Issues. London: Sage Publications, pp. 24-60.

Masso, Iivi Anna 2010. Kas tõesti nõukogudenostalgia? [Indeed - Soviet Nostalgia?] http://uuseesti.ee/26532, last accessed on 26 November 2011.

Misztal, Barbara A. 2003. Theories of Social Remembering. Philadelphia: Open University Press.

Mohrmann, Ruth E. 1991. Dingliche Erinnerungskultur im privaten Bereich. In: B. Bönisch-Brednich \& R. W. Brednich \& H. Gerndt (eds.) Erinnern und Vergessen. Vorträge des 27. Deutschen Volkskundekongresses Göttingen 1989 (Beiträge zur Volkskunde in Niedersachsen 5), Göttingen: V. Schmerse, pp. 209-217.

Nugin, Raili 2011. Coming of Age in Transition. Some Self-Reflexive Social Portraits of the 1970s Cohort in Estonia. PhD thesis. Tallinn: Tallinna Ülikool. e-publikatsioon. http://www.tlu.ee/files/news/3619/Nugin7b2dcbdb808e7e77152ca73f0390ffdb.pdf, last accessed on 4 December 2011.

Paulus, Karin 2011. Tootedisain. Asjad minu elus. [Industrial Design. Things in My Life.] Tallinn: Eesti Kunstiakadeemia.

Paju, Laura \& Võsu, Ester 2008. ERKI moeshow kui karnevallik nähtus 1980. aastate Nõukogude Eestis. [Students' Fashion Show at the SAIE (State Art Institute of the Estonian SSR) as a Carnivalesque Phenomenon in Soviet Estonia.] Kunstiteaduslikke Uurimusi / Studies on Art and Architecture 17(4), pp. 31-56.

Rigney, Ann 2008. The Dynamics of Rememberance: Texts Between Monumentality and Morphing. In: A. Erll \& A. Nünning (eds.) Cultural Memory Studies. An International and Interdisciplinary Handbook. Berlin: Walter de Gruyter, pp. 345-356.

Ross, Johanna 2010. Mäletamispaine on nõudnud veel ühe ohvri. [Anxiety of remembering has claimed another victim] Vikerkaar, Vol. 3. http://www.vikerkaar. ee/?page=Arhiiv\&a_act=article\&a_number=5068, last accessed on 4 December 2011.

Schwartz, Barry 2000. Abraham Lincoln and the forge of national memory. Chicago: The University of Chicago Press.

Teder, Tarmo 2009. Soome televisioon oli meile hea võõrasema. Intervjuu Jaak Kilmiga. [Finnish Television was a good step-mother for us. Interview with Jaak Kilmi.] Sirp, April 3. http://www.sirp.ee/index.php?option=com_content\&view=article\& $\mathrm{id}=8464$ : soome-televisioon-oli-meile-hea-voorasema\&catid=4:film\&Itemid=3\&is sue $=3246$, last accessed on 4 December 2011 . 
Vadi, Urmas 2008. Kohtumine tundmatuga. [Touched by the Unknown.] Pärnu: Jumalikud Ilmutused.

Vadi, Urmas 2010. Kirjad tädi Annele. [Letters to Aunt Anne.] Pärnu: Jumalikud Ilmutused.

Yurchak, Alexei 2005. Everything Was Forever, Until It Was No More. The Last Soviet Generation. Princenton: Princenton University Press.

Weisbrod, Bernd. 2007. Cultures of Change: Generations in the Politics and Memory of Modern Germany. In: S. Lovell (ed.) Generations in Twentieth-Century Europe. New York: Palgrave Macmillan, pp. 19-35.

Welzer, Harald 2002. Das kommunikative Gedächtnis. Eine Theorie der Erinnerung. München: Beck.

Welzer, Harald 2008. Communicative Memory. In: A. Erll \& A. Nünning (eds.) Cultural Memory Studies. An International and Interdisciplinary Handbook. Berlin: Walter de Gruyter, pp. 285-298.

Wertsch, James 2002. Voices of Collective Remembering. Cambridge: Cambridge University Press. 